\section{'Honeycrisp' Apple (Malus domestica Borkh.) Fruit Response to Controlled Atmosphere Storage with the Low Oxygen Limit Established by Monitoring Chlorophyll Fluorescence}

\author{
James Mattheis and David R. Rudell \\ U.S. Department of Agriculture, Agricultural Research Service, Tree Fruit \\ Research Laboratory, 1104 N. Western Avenue, Wenatchee, WA 98801
}

Additional index words. fruit quality, dynamic controlled atmosphere, physiological disorders, soft scald, internal browning, calyx-end leather blotch, core flush

\begin{abstract}
Postharvest management of apple fruit ripening using controlled atmosphere (CA) storage can be enhanced because CA oxygen concentration is decreased to close to the anaerobic compensation point (ACP). Monitoring fruit chlorophyll fluorescence (CF) is a technology to assess fruit response to low $\mathrm{pO}_{2}$ as fluorescence increases as $\mathrm{pO}_{2}$ reaches a critically low concentration. This type of $\mathrm{pO}_{2}$ management has been referred to as dynamic atmosphere storage (DCA). Use of very low $\mathrm{pO}_{2}$ can enhance post-storage apple fruit quality for many cultivars, allowing better firmness retention and prevention of superficial scald, compared with fruit stored at higher $\mathrm{pO}_{2}$ during $\mathrm{CA}$. 'Honeycrisp' is a chilling-sensitive cultivar with little risk of firmness loss or superficial scald during storage; however, other aspects of fruit-quality loss during storage, including soluble solids content (SSC), titratable acidity (TA), peel greasiness, and physiological disorder development may be impacted by $\mathrm{pO}_{2}$. A 2-year study was conducted to identify 'Honeycrisp' fruit-quality impacts of $\mathrm{CA}$ storage with a low- $\mathrm{pO}_{2}$ setpoint determined by using $\mathrm{CF}$. 'Honeycrisp' apples were held 7 days at $10{ }^{\circ} \mathrm{C}$ after harvest, then at $3{ }^{\circ} \mathrm{C}$. An additional treatment with 1-methylcyclopropene (1-MCP) was conducted in year two. CA was established 48 hours after transfer to $3{ }^{\circ} \mathrm{C}$. In both years, fruit $\mathrm{CF}$ increased when $\mathrm{pO}_{2}$ decreased to $\approx 0.3 \mathrm{kPa} \mathrm{O}$ and then decreased after $\mathrm{pO}_{2}$ was increased to $0.5 \mathrm{kPa}$.

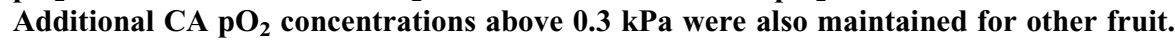
Fruit internal disorder incidence increased as $\mathrm{pO}_{2}$ decreased and with 1-MCP use. Changes in SSC, TA, and peel yellowing were inconsistently reduced by storage at lower $\mathrm{pO}_{2}$. Peel greasiness did not develop in either year. $\mathrm{CA}$ did not impact the incidence of chilling disorders regardless of $\mathrm{pO}_{2}$. Results indicate some aspects of 'Honeycrisp' fruit quality can be enhanced as $\mathrm{CA}_{\mathrm{pO}}$ decreases; however, $\mathrm{pO}_{2}$ above the low $\mathrm{pO}_{2}$ threshold did not prevent internal physiological disorder development.
\end{abstract}

'Honeycrisp' apple exhibits little loss of firmness over an extended cold storage period in air or CA (Tong et al., 1999; Watkins and Nock, 2012). Other aspects of ripening progress during storage, including loss of titratable acidity and soluble solids content,

Received for publication 3 Sept. 2020. Accepted for publication 18 Nov. 2020.

Published online 30 December 2020.

Financial support for this research received from the Washington Tree Fruit Research Commission and AgroFresh, Inc. Mention of trade names or commercial products in this publication is solely for the purpose of providing specific information and does not imply recommendation or endorsement by the U.S. Department of Agriculture.

We thank Dave Buchanan, Janie Countryman, and Dr. David Felicetti for their excellent technical assistance.

J.M. is the corresponding author. E-mail: james. mattheis@usda.gov.

This is an open access article distributed under the CC BY-NC-ND license (https://creativecommons. org/licenses/by-nc-nd/4.0/). able acidity (DeLong et al., 2004b; Zanella et al., 2005), as well as reduced incidence of superficial scald (Zanella, 2003), compared with storage in higher $\mathrm{pO}_{2}$ during CA. Storage of apples at $\mathrm{pO}_{2}$ close to the LOL has been suggested to provide a nonchemical means for physiological disorder control, particularly for superficial scald in organic fruit, for which synthetic postharvest chemicals is prohibited (DeLong et al., 2007).

CA storage of 'Honeycrisp' has not consistently been observed to enhance poststorage fruit quality compared with air storage (Contreras et al., 2014; DeEll et al., 2015, 2016; El-Shiekh et al., 2002; Mattheis et al., 2017; Serban et al., 2019; Watkins and Nock, 2012). However, these studies were conducted using $\mathrm{pO}_{2}$ setpoints above $1 \mathrm{kPa}$. How 'Honeycrisp' CA storage at $\mathrm{pO}_{2}$ less than 1 impacts fruit quality attributes other than firmness (DeLong et al., 2004a) has not been reported.

The objective of this research was to evaluate 'Honeycrisp' apple response to CA storage under a range of low $\mathrm{pO}_{2}$, with the lowest setpoint determined based on fruit $\mathrm{CF}$.

\section{Materials and Methods}

Plant material and cold storage procedures. 'Honeycrisp' (Malus ×domestica Borkh.) apples from a commercial orchard in central Washington State were used in two consecutive seasons. Apples determined by the grower to be horticulturally mature were obtained the day of harvest. Fruit without external defects were placed on pressed-fiber trays, and then these trays were put into cardboard boxes (control fruit), or in year two were placed into an $800-\mathrm{L}$ gas-tight metal cabinet for 1-MCP treatment. The 1-MCP treatment was conducted in a cold room separate from that in which control fruit were held; both cold rooms were maintained at $10^{\circ} \mathrm{C}$. Fruit on trays in the metal tank were exposed to 42 $\mu \mathrm{mol} \cdot \mathrm{L}^{-1}$ 1-MCP (AgroFresh, Inc., Spring House, PA) for $24 \mathrm{~h}$, then the trays were removed from the metal tank, placed into cardboard boxes, and moved to the same cold room as the controls. The controls and 1-MCP-treated fruit were held for $7 \mathrm{~d}$ at $10{ }^{\circ} \mathrm{C}$, then they were moved to a cold room held at $3{ }^{\circ} \mathrm{C}$ for the remainder of the storage period. Fruit stored in air remained packed in cardboard boxes, while fruit for CA were removed from boxes and stored on trays in sealed, $0.14-\mathrm{m}^{3}$ CA chambers. Two CA chambers were used to monitor apple chlorophyll fluorescence using the HarvestWatch system (Satlantic Inc., Halifax, N.S., Canada). CA was generated and maintained as described previously (Mattheis et al., 2017). After $2 \mathrm{~d}$ at $3{ }^{\circ} \mathrm{C}, 1.5$ and $2.0 \mathrm{kPa} \mathrm{O}$ were established in years one and two, respectively, with $\mathrm{pCO}_{2}$ at $0.5 \mathrm{kPa}$ in both years. After 2 additional days, $\mathrm{pO}_{2}$ was reduced in the two chambers with the $\mathrm{CF}$ monitoring system until an increase in $\mathrm{CF}$ occurred. The $\mathrm{pO}_{2}$ at which the CF increase occurred was identified as the LOL. Following the identification of the LOL, $\mathrm{pO}_{2}$ settings 
for additional CA chambers containing sample fruit were set in year one at the LOL: $\mathrm{LOL}+0.2 \mathrm{kPa}$; LOL $+0.5 \mathrm{kPa}$; and $1.5 \mathrm{kPa}$. In year two, $\mathrm{pO}_{2}$ setpoints were the following: $\mathrm{LOL}+0.2 \mathrm{kPa} ; 1.0 \mathrm{kPa}$ and $2.0 \mathrm{kPa}$. In both years, additional fruit at $\mathrm{pO}_{2}$ set at the $\mathrm{LOL}+0.2 \mathrm{kPa}$ were monitored using the HarvestWatch system. The CA system was operated using commercial controls (Empire Controls, Chelan, WA) as described previously by Mattheis et al. (2017). Storage duration was 4 and 8 months in both years. When CA chambers were resealed after removing fruit after 4 months, chambers were purged with $\mathrm{N}_{2}$ and $\mathrm{CO}_{2}$ sufficient to reestablish the $\mathrm{kPO}_{2}$ and $\mathrm{kCO}_{2}$ setpoints within $1 \mathrm{~h}$.

Fruit quality assessment. Fruit were assessed at harvest as well as the day of and $7 \mathrm{~d}$ after removal from cold storage. Post-cold storage temperature was $20{ }^{\circ} \mathrm{C}$. All fruit evaluation procedures were as described previously by Mattheis et al. (2017).

Experimental design and statistical analysis. Experiments were conducted with a completely randomized design, with 3 replicates of 6 individual fruit (starch, internal ethylene concentration, firmness, peel ground color); 9 replicates prepared with 2 fruit (soluble solids content and titratable acidity); 4 replicates containing 4 fruit (ethylene production); 6 replicates of 12 fruit for physiological disorders, for each storage atmosphere/storage duration combination. Statistical analyses were conducted with SAS 9.4 (SAS Institute, Raleigh, NC). Disorder incidence was arcsine square root transformed before analysis. Significant treatment differences for fruit quality attributes and storage disorders were identified using analysis of variance and treatment means separated using Tukey's honestly significant difference. Maturity at harvest results by year were compared using the SAS $t$ test procedure.

\section{Results}

At harvest, values for starch index, peel ground color, and SSC were higher, titratable acidity lower, and internal ethylene concentration (IEC) and firmness similar for year one compared with year two (Table 1). The LOL was $0.3 \mathrm{kPa}$ in both years. Based on these results, in year one the lowest $\mathrm{pO}_{2}$ concentrations were at the LOL of $0.3 \mathrm{kPa}$ $\mathrm{O}_{2}$ and $0.5 \mathrm{kPa}$. In year two, the lowest $\mathrm{pO}_{2}$ was $0.2 \mathrm{kPa}$ higher than the LOL, $0.5 \mathrm{kPa}$. During the storage period in both years, $\mathrm{CF}$ of fruit held at $0.5 \mathrm{kPa}$ did not exhibit an abrupt increase as had been observed during determination of the LOL.

Incidence of soft scald in both years was low, and there was no soggy breakdown in year one (Tables 2 and 3 ). In year one there were no storage treatment effects on soft scald after 4 months, and the disorder was present only on fruit stored at 0.3 and $0.5 \mathrm{kPa}$ $\mathrm{O}_{2}$ at 8 months. No treatment effects on soft scald and soggy breakdown were present in year two. Internal browning incidence increased as storage $\mathrm{pO}_{2}$ decreased in both years and with 1-MCP treatment in year two-although the symptoms differed between years (radial browning in year one, diffuse browning in year two). Cortex cavities, calyx-end peel browning, and core flush developed only in year two, with calyx-end leather blotch highest in fruit treated with 1$\mathrm{MCP}$ and stored at $0.5 \mathrm{kPa} \mathrm{O}$. Core flush only developed in 1-MCP fruit stored in air. The incidence of nonchilling disorders increased as $\mathrm{pO}_{2}$ decreased, in both years.

Peel background color ratings were lower (greener) as $\mathrm{pO}_{2}$ decreased and for 1-MCPtreated fruit stored in air. Control fruit stored in air had the highest peel color (yellow) rating. The $\mathrm{pO}_{2}$ influenced $\mathrm{SSC}$ and TA in both years, with fruit stored in air having the lowest values. In year one after 8 months, TA retention increased as $\mathrm{pO}_{2}$ decreased; while in year two, an atmosphere $\times 1$-MCP interaction influenced TA values. Within some but not all $\mathrm{pO}_{2}$ treatments, TA was higher for $1-\mathrm{MCP}$ fruit. There were no $\mathrm{pO}_{2}$ or 1-MCP treatment effects on firmness. IEC was highest in air-stored fruit in both years (controls in year two). Ethylene production was influenced by an atmosphere $\times 1-\mathrm{MCP}$ interaction in year two at both 4 and 8 months.

\section{Discussion}

As 'Honeycrisp' loses little if any firmness during storage (Tong et al., 1999; Wargo and Watkins, 2004) and has not been reported to be susceptible to superficial scald, the benefit of CA storage resides in retention of other aspects of fruit quality and limiting disorder development (DeEll et al., 2015; DeLong et al., 2006; Mattheis et al., 2017; Watkins and Nock, 2012). While the results herein show CA storage reduces SSC and TA loss and development of peel yellow color compared with fruit stored in air, increased incidence of soft scald in one year and nonchilling disorders in both years as $\mathrm{pO}_{2}$ setpoint decreased reduces the potential use for $\mathrm{CA}$ at and near the LOL. These results are consistent with responses in 'Anjou' pear fruit, where internal browning developed when $\mathrm{pO}_{2}$ was held at $0.2 \mathrm{kPa}$ above the LOL (Mattheis and Rudell, 2011; Mattheis et al., 2013). While increased internal browning risk has been observed in other apple cultivars as $\mathrm{pO}_{2}$ decreases (Watkins and Mattheis, 2019), soft scald risk has not been reported to have a similar relationship. As the relationship between soft scald and $\mathrm{pO}_{2}$ was observed in only one of the two years and incidence was relatively low, more research is needed to conclusively establish that $\mathrm{pO}_{2}$ can influence soft scald development.

While the range of $\mathrm{pO}_{2}$ values in the two seasons were different, internal browning injury increased in both years as $\mathrm{pO}_{2}$ decreased. The lowest $\mathrm{pO}_{2}$ in the first year was at the LOL where a high \% of internal browning occurred; but internal browning also occurred at $0.5 \mathrm{kPa} \mathrm{O}_{2}, 0.2 \mathrm{kPa}$ above the measured LOL in both years, indicating that a risk for internal browning exists even above the LOL. The highest $\mathrm{pO}_{2}$ in year two, $2 \mathrm{kPa}$, was above that of year one to attempt to avoid (unsuccessfully) internal browning that had occurred at the highest $\mathrm{pO}_{2}$ in year one, $1.5 \mathrm{kPa}$. Development of nonchilling disorders in fruit stored at the highest $\mathrm{pO}_{2}$ in both years, compared with no injury in fruit stored in air, is consistent with a risk of disorder development even at relatively high $\mathrm{pO}_{2}$ (Contreras et al., 2014; Watkins and Nock, 2012).

The pre-CA storage conditioning protocol can impact 'Honeycrisp' physiological disorder risk with conditioning temperature (Contreras et al., 2014) and duration (DeEll et al., 2016), both factors influencing CA injury. The conditioning protocol used here, $10{ }^{\circ} \mathrm{C}$ for $7 \mathrm{~d}$, is not optimum for CA disorder avoidance based on that previous work. Whether use of higher conditioning temperature and/or longer duration would reduce disorder risk at low $\mathrm{pO}_{2}$ is unknown-as is how higher temp/longer duration conditioning would influence the low $\mathrm{pO}_{2}$ impacts on fruit quality, particularly SSC, TA, and peel color. Longer conditioning duration can enhance lenticel breakdown, bitter pit/blotch, and peel greasiness (DeEll et al., 2016).

Higher disorder incidence in 1-MCPtreated fruit stored in $\mathrm{CA}$ is consistent with previous reports (DeEll et al., 2015, Lum et al., 2016). Higher internal browning in 1MCP-treated fruit compared with control fruit stored only at 0.5 and $1.0 \mathrm{pO}_{2}$ may indicate fruit in this study had a lower susceptibility to this disorder compared with that used by Lum et al. (2016), and that injury occurred only when fruit were stored in the

Table 1. 'Honeycrisp' fruit maturity at harvest and the low oxygen limit (LOL) in 2 consecutive years. Values are means; $\mathrm{n}=3$ replicates of 6 fruit for internal ethylene concentration (IEC), starch index (Starch: 1 = full starch, $6=$ clear), firmness, and peel ground color $(1=$ green, $5=$ yellow); $\mathrm{n}=9$ replications of 2 fruit for titratable acidity (TA) and soluble solids content (SSC); and $n=2$ for LOL. LOL was determined using the HarvestWatch system. Mean comparison by Student's $t$ test.

\begin{tabular}{cccccccc}
\hline $\mathrm{Yr}$ & IEC $\left(\mathrm{mmol} \cdot \mathrm{m}^{-3}\right)$ & Starch $(1-6)$ & Firmness $(\mathrm{N})$ & Peel color $(1-5)$ & SSC $(\%)$ & TA $(\%)$ & LOL $\left(\mathrm{kPa} \mathrm{O}_{2}\right)$ \\
\hline 1 & 0.94 & 6.0 & 69.9 & 3.8 & 0.500 & 13.5 & 0.3 \\
2 & 0.71 & 5.5 & 67.2 & 2.9 & 0.589 & 13.1 & 0.3 \\
& NS & $*$ & NS & $* * *$ & $*$ & NS \\
\hline
\end{tabular}

NS, $* * * *$ Nonsignificant or significant at $P \leq 0.05$ or 0.001 , respectively. 
Table 2. 'Honeycrisp' fruit quality and physiological disorders after storage, year one. Fruit were held $7 \mathrm{~d}$ at $10{ }^{\circ} \mathrm{C}$ after harvest then at $3{ }^{\circ} \mathrm{C}$ in air or a $\mathrm{CA}$ with 0.3 to $1.5 \mathrm{kPa} \mathrm{O}$ with $0.5 \mathrm{kPa} \mathrm{CO}_{2}$ for 4 or $8 \mathrm{mo}$. Apples were held $7 \mathrm{~d}$ at $20^{\circ} \mathrm{C}$ after removal from cold storage. Values are means; $\mathrm{n}=6$ replicates of 12 fruit for soft scald (SS) and radial internal browning (RIB); $n=3$ replicates of 6 fruit for peel ground color (PGC) and firmness (Firm); $n=9$ replicates of 2 fruit for soluble solids content (SSC) and titratable acidity (TA); and $n=4$ replicates of 4 fruit for ethylene production $\left(\mathrm{C}_{2} \mathrm{H}_{4}\right)$. Means within columns within months followed by different letters are significantly different according to Tukey's honestly significant difference.

\begin{tabular}{|c|c|c|c|c|c|c|c|c|}
\hline Months & $\mathrm{O}_{2}(\mathrm{kPa})$ & SS (\%) & RIB (\%) & PGC (1-5) & Firm $(\mathrm{N})$ & SSC (\%) & TA (\%) & $\mathrm{C}_{2} \mathrm{H}_{4}\left(\eta \mathrm{mol} \cdot \mathrm{g}^{-1} \cdot \mathrm{s}^{-1}\right)$ \\
\hline \multirow{3}{*}{4} & 0.8 & 0 & 11 & $4.3 \mathrm{~b}$ & 69.0 & $12.9 \mathrm{a}$ & $0.413 \mathrm{a}$ & $0.31 \mathrm{~b}$ \\
\hline & 0.5 & 3 & 3 & $4.3 \mathrm{~b}$ & 65.5 & $12.7 \mathrm{ab}$ & $0.346 \mathrm{bc}$ & $0.34 \mathrm{~b}$ \\
\hline & & NS & NS & $* *$ & NS & $* *$ & $* * *$ & $* * *$ \\
\hline \multirow[t]{4}{*}{8} & Air & $0 \mathrm{~b}$ & $0 \mathrm{c}$ & $5.0 \mathrm{a}$ & 61.2 & $11.4 \mathrm{c}$ & $0.249 \mathrm{~d}$ & $0.91 \mathrm{a}$ \\
\hline & 1.5 & $0 \mathrm{~b}$ & $6 \mathrm{bc}$ & $5.0 \mathrm{a}$ & 66.5 & $11.6 \mathrm{c}$ & $0.325 \mathrm{c}$ & $0.34 \mathrm{c}$ \\
\hline & 0.3 & $6 \mathrm{ab}$ & $31 \mathrm{a}$ & $4.0 \mathrm{~b}$ & 66.1 & $12.7 \mathrm{ab}$ & $0.387 \mathrm{a}$ & $0.25 \mathrm{c}$ \\
\hline & & $*$ & $* *$ & $* *$ & NS & $* * *$ & $* * *$ & $* * *$ \\
\hline
\end{tabular}

Ns, $* * *, * * *$ Nonsignificant or significant at $P \leq 0.05,0.01$, or 0.001 , respectively.

Table 3. 'Honeycrisp' fruit quality and physiological disorders after storage, year two. Fruit were held $7 \mathrm{~d}$ at $10{ }^{\circ} \mathrm{C}$ after harvest, then at $3{ }^{\circ} \mathrm{C}$ in air or a $\mathrm{CA}$ with 0.3 to $1.5 \mathrm{kPa} \mathrm{O}$ with $0.5 \mathrm{kPa} \mathrm{CO}$. Apples were held $7 \mathrm{~d}$ at $20^{\circ} \mathrm{C}$ after removal from cold storage. Values are means; $\mathrm{n}=6$ replicates of 12 fruit for soft scald (SS), soggy breakdown (SB), diffuse internal browning (DIB), cavities (Cav), calyx-end leather blotch (CLB), core flush (CF), and total nonchilling disorders (TNC); $\mathrm{n}=3$ replicates of 6 fruit for peel ground color (PGC) and firmness (Firm); $\mathrm{n}=9$ replicates of 2 fruit for soluble solids content (SSC) and titratable acidity (TA); and $n=4$ replicates of 4 fruit for ethylene production $\left(\mathrm{C}_{2} \mathrm{H}_{4}\right)$. Means within columns within month followed by different letters are significantly different according to Tukey's honestly significant difference.

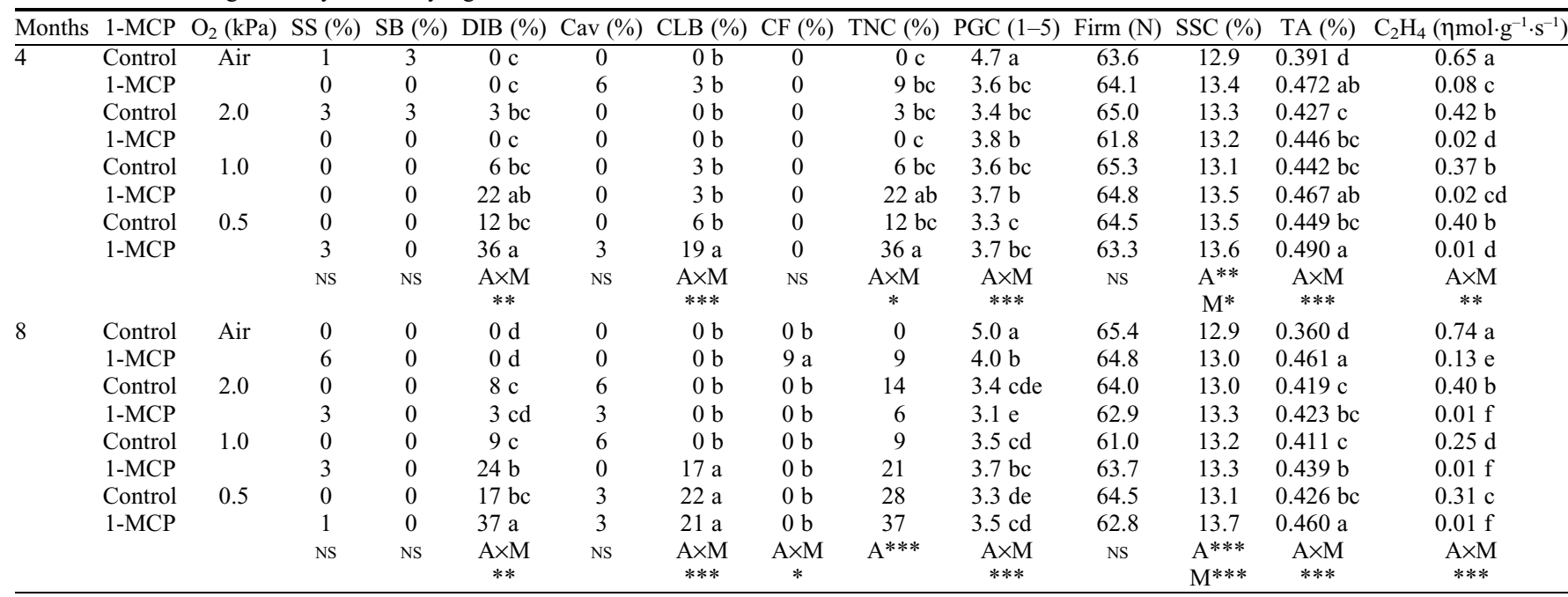

$\mathrm{A}=$ atmosphere $\mathrm{M}=1-\mathrm{MCP} ; \mathrm{A} \times \mathrm{M}=$ atmosphere $\times 1-\mathrm{MCP}$ interaction.

Ns, $*, * *, * * *$ Nonsignificant or significant at $P \leq 0.05,0.01$, or 0.001 , respectively

low- $\mathrm{pO}_{2}$ atmospheres that induced more stress compared with that at higher $\mathrm{pO}_{2}$.

CA-stored 'Honeycrisp' with or without previous 1-MCP treatment can have higher SSC and TA compared with controls stored in air (DeEll et al., 2015). Fruit with higher TA received higher sensory scores for acid taste in the same study. Impacts of CA with or without 1-MCP on other sensory components indicates additional impacts of these storage technologies on post-storage fruit quality. Control fruit stored in air in this study always had the lowest TA, illustrating the value of $\mathrm{CA}$ and/or 1-MCP for preserving this quality attribute for consumers preferring acid taste. However, the lack of consistently higher TA values accompanying decreased $\mathrm{CA} \quad \mathrm{pO}_{2}$ questions the need for very low $\mathrm{pO}_{2}$ for 'Honeycrisp'. What, if any, impact $\mathrm{pO}_{2}$ has on 'Honeycrisp' peel greasiness development is undetermined, because greasiness did not develop in either year of the study.
Factors contributing to the difference in internal browning symptoms in the 2 years of this study are unknown. Research with 'Gala' apple has shown storage temperature and 1-MCP treatment can impact internal browning symptom development (Lee et al., 2016). As the postharvest temperature protocol used in both years in this study was identical, and internal browning symptoms in year two when 1-MCP was used were identical in control and treated fruit, other factors, perhaps preharvest conditions (Lachapelle et al., 2013, 2017; Tong et al., 2016), may have contributed to the difference between years. Core browning in year two in fruit stored in air but only in 1-MCPtreated fruit is consistent with results reported by Serban et al. (2019) but contrasts a previous report (Watkins and Nock, 2012) where the disorder was present in fruit stored in CA and incidence was lowest in 1-MCP-treated fruit.
Symptoms of the calyx-end peel injury detected in this study were consistent with 'Honeycrisp' peel leather blotch reported previously (DeEll et al., 2016; Mattheis et al., 2017; Serban et al., 2019). Thus $\mathrm{pCO}_{2}$ (Anderson, 1967) and 1-MCP treatment (DeEll et al., 2015) both influence development of peel $\mathrm{CO}_{2}$ injury, the symptoms of which are consistent with what was observed here, and increased incidence with decreased $\mathrm{O}_{2} \mathrm{kPa}$ may indicate increased $\mathrm{CO}_{2}$ sensitivity as storage $\mathrm{O}_{2} \mathrm{kPa}$ decreases or may show that the disorder is a form of low-oxygen injury.

The low-oxygen threshold identified by monitoring $\mathrm{CF}$ in both years was $0.1 \mathrm{kPa}$ less than that reported previously for 'Honeycrisp' (DeLong et al., 2004b; Wright et al., 2010). Use of a range of $\mathrm{pO}_{2}$ above the threshold revealed a relationship between $\mathrm{pO}_{2}$ and internal browning that developed at $\mathrm{pO}_{2}$ well above the threshold value. As most of the fruit evaluated after storage was not subject to the initial low- $\mathrm{pO}_{2}$ 
regime used to establish the low- $\mathrm{O}_{2}$ threshold, internal browning could not have resulted from a relatively brief low- $\mathrm{O}_{2}$ exposure at the threshold value. Development of injury in this study, compared with the lack of injury in previously reported work (DeLong et al., 2004b), may reflect seasonal, climatic, orchard, or other factors that can influence apple fruit disorder development (Watkins and Mattheis, 2019). The absence of an abrupt change in $\mathrm{CF}$ during the storage period after $\mathrm{pO}_{2}$ had been increased to $0.5 \mathrm{kPa} \mathrm{O}_{2}$, $0.2 \mathrm{kPa}$ above the threshold value, indicates the metabolic events resulting in internal browning in this study did not result in a change in CF typical for establishing the low$\mathrm{O}_{2}$ threshold.

Postharvest management of 'Honeycrisp' largely focuses on disorder avoidance, both $\mathrm{CI}-$ and CA-related internal browning. Benefits of CA to fruit-quality maintenance reside outside of firmness and can be obtained at $\mathrm{pO}_{2}$ well above the $\mathrm{CF}$ low- $\mathrm{O}_{2}$ threshold. Considering the risk of internal browning based on this study's results, $\mathrm{CA}$ at $\mathrm{pO}_{2}$ values well above the low- $\mathrm{O}_{2}$ threshold (as determined here using chlorophyll fluorescence) provides fruit-quality benefits with a relatively low risk of CA-induced internal disorders, compared with fruit stored in air.

\section{Literature Cited}

Anderson, R.E. 1967. Experimental storage of eastern-grown 'Delicious' apples in various controlled atmospheres. Proc. Amer. Soc. Hort. Sci. 91:810-820.

Contreras, C.N., N. Alsmairat, and R. Beaudry. 2014. Prestorage conditioning and diphenylamine improve resistance to controlled-atmosphere-related injury in 'Honeycrisp' apples. HortScience 49:76-81, doi: 10.21273/HORTSCI.49.1.76.

DeEll, J.R., O. van Kooten, R.K. Prange, and D.P. Murr. 1999. Applications of chlorophyll fluorescence techniques in post-harvest physiology. Hort. Rev. 23:69-107.

DeEll, J.R., B. Ehsani-Moghaddam, A.J. Bowen, and I. Lesschaeve. 2015. Effects of 1-methycyclopropene and controlled atmosphere storage on the quality of 'Honeycrisp' apples. Acta Hort. 1071:483-488, doi: 10.17660/ActaHortic. 2015.1071.62.

DeEll, J.R., G.G. Lum, and B. Ehsani-Moghaddam. 2016. Effects of delayed controlled atmosphere storage on disorder development in 'Honeycrisp' apples. Can. J. Plant Sci. 96:621-629, doi: 10.1139/cjps-2016-0031.

DeLong, J.M., R.K. Prange, and P.A. Harrison. 2004a. The influence of pre-storage delayed cooling on quality and disorder incidence in 'Honeycrisp' apple fruit. Postharvest Biol. Technol. 34:353-358, doi: 10.1016/j.postharvbio. 2004.10.001.

DeLong, J.M., R.K. Prange, J.C. Leyte, and P.A. Harrison. 2004b. A new technology that determines low-oxygen thresholds in controlledatmosphere-stored apples. HortTechnology
14:262-266, doi: 10.21273/HORTTECH.14. 2.0262 .

DeLong, J.M., R.K. Prange, P.A. Harrison, C.G. Embree, D.S. Nichols, and H.A. Wright. 2006. The influence of crop-load, delayed cooling and storage atmosphere on post-storage quality of 'Honeycrisp' apples. J. Hort. Sci. Biotechnol. 81:391-396, doi: 10.1080/14620316. 2006.11512078.

DeLong, J.M., R.K. Prange, and P.A. Harrison. 2007. Chlorophyll fluorescence based low $\mathrm{O}_{2}$ storage of organic 'Cortland' and 'Delicious' apples. Acta Hort. 737:31-37, doi: 10.17660/ ActaHortic.2007.737.3.

El-Shiekh, A.F., C.B.S. Tong, J.J. Luby, E.E. Hoover, and D.S. Bedford. 2002. Storage potential of cold-hardy apple cultivars. J. Amer. Pomol. Soc. 56:34-45.

Lachapelle, M., G. Bourgeois, J. DeEll, K.A. Stewart, and P. Séguin. 2013. Modeling the effect of preharvest weather conditions on the incidence of soft scald in 'Honeycrisp' apples. Postharvest Biol. Tech. 85:57-66, doi: 10.1016/j.postharvbio.2013.04.004.

Lachapelle, M., G. Bourgeois, J. DeEll, K.A. Stewart, and P. Séguin. 2017. Modeling the effect of preharvest weather conditions on the incidence of soggy breakdown in 'Honeycrisp' apples. HortScience 52:756-763, doi: 10.21273/ HORTSCI10761-16.

Lee, J., J.P. Mattheis, and D.R. Rudell. 2016. Storage temperature and 1-methylcyclopropene treatment affect storage disorders and physiological attributes of 'Royal Gala' apples. HortScience 51:84-93, doi: 10.21273/HORTSCI. 51.1.84.

Lum, G.B., C.J. Brikis, K.L. Deyman, S. Subedi, J.R. DeEll, B.J. Shelp, and G.G. Bozzo. 2016. Pre-storage conditioning ameliorates the negative impact of 1-methylcyclopropene on physiological injury and modifies the response of antioxidants and $\gamma$-aminobutyrate in 'Honeycrisp' apples exposed to controlled-atmosphere conditions. Postharvest Biol. Technol. 116:115128, doi: 10.1016/j.postharvbio.2016.01.013.

Mattheis, J.P., D.R. Rudell, and I. Hanrahan. 2017. Impacts of 1-methylcyclopropene and controlled atmosphere established during conditioning on development of bitter pit in 'Honeycrisp' apples. HortScience 52:132137, doi: 10.21273/HORTSCI11368-16.

Mattheis, J.P. and D. Rudell. 2011. Responses of 'd'Anjou' pear (Pyrus communis L.) fruit to storage at low oxygen set-points determined by monitoring fruit chlorophyll fluorescence. Postharvest Biol. Technol. 60:125-129, doi: 10.1016/j.postharvbio.2010.12.007.

Mattheis, J., D. Felicetti, and D.R. Rudell. 2013. Pithy brown core in 'd'Anjou' pear (Pyrus communis L.) fruit developing during controlled atmosphere storage at $\mathrm{pO}_{2}$ determined by monitoring chlorophyll fluorescence. Postharvest Biol. Technol. 86:259-264, doi: 10.1016/j.postharvbio.2013.07.006.

Serban, C., L. Kalcsits, J. DeEll, and J.P. Mattheis. 2019. Responses of 'Honeycrisp' apples to short-term controlled atmosphere storage established during temperature conditioning.
HortScience 54:1532-1539, doi: 10.21273/ HORTSCI14182-19.

Tong, C., D. Kruger, Z. Vickers, D. Bedford, J. Luby, A. El-Shiekh, K. Shackel, and H. Ahmadi. 1999. Comparison of softeningrelated changes during storage of 'Honeycrisp' apple, its parents, and 'Delicious'. J. Amer. Soc. Hort. Sci. 124:407-415, doi: 10.21273/ JASHS.124.4.407.

Tong, C.B.S., D.S. Bedford, J.J. Luby, F.M. Propsom, R.M. Beaudry, J.P. Mattheis, C.B. Watkins, and S.A. Weis. 2003. Location and temperature effects on soft scald in 'Honeycrisp' apples. HortScience 38:1153-1155, doi: 10.21273/HORTSCI.38.6.1153.

Tong, C.B.S., H.-Y. Chang, J.K. Boldt, Y.B. Ma, J.R. DeEll, R.E. Moran, G. Bourgeois, and D. Plouffe. 2016. Diffuse flesh browning in 'Honeycrisp' apple fruit is associated with low temperatures during fruit growth. HortScience 51:1256-1264, doi: 10.21273/ HORTSCI11179-16.

Wargo, J.M. and C.B. Watkins. 2004. Maturity and storage quality of 'Honeycrisp' apples. HortTechnology 14:496-499, doi: 10.21273/ HORTTECH.14.4.0496.

Watkins, C.B., J.F. Nock, S.A. Weis, S. Jayanty, and R.M. Beaudry. 2004. Storage temperature, diphenylamine, and pre-storage delay effects on soft scald, sorry breakdown and bitter pit of 'Honeycrisp' apples. Postharvest Biol. Technol. 32:213-221, doi: 10.1016/j.postharvbio. 2003.11.003.

Watkins, C.B., M. Erkan, J.F. Nock, K.A. Iungerman, R.M. Beaudry, and R.E. Moran. 2005. Harvest date effects on maturity, quality, and storage disorders of 'Honeycrisp' apples. HortScience 40:164-169, doi: 10.21273/HORTSCI.40. 1.164 .

Watkins, C.B. and J.F. Nock. 2012. Controlledatmosphere storage of 'Honeycrisp' apples. HortScience 47:886-892, doi: 10.21273/ HORTSCI.47.7.886.

Watkins, C.B. and J.P. Mattheis. 2019. Apple, p. 165-206. In: S. Tonetto de Freitas and S. Pareek (eds.). Postharvest physiological disorders in fruits and vegetables. CRC Press, Boca Raton, FL, doi: 10.1201/b22001.

Wright, H., J. DeLong, P.A. Harrison, A.H.L.A.N. Gunawardena, and R.K. Prange. 2010. The effect of temperature and other factors on chlorophyll $a$ fluorescence and the lower oxygen limit in apples (Malus domestica). Postharvest Biol. Technol. 55:21-28, doi: 10.1016/ j.postharvbio.2009.07.011.

Zanella, A. 2003. Control of apple superficial scald and ripening-A comparison between 1methycyclopropene and diphenylamine postharvest treatments, initial low oxygen stress and ultra-low oxygen storage. Postharvest Biol. Technol. 27:69-78, doi: 10.1016/S09255214(02)00187-4.

Zanella, A., P. Cazzanelli, A. Panarese, M. Coser, M. Cecchinel, and O. Rossi. 2005. Fruit fluorescence response to low oxygen stress: Modern storage technologies compared to 1-MCP treatment of apple. Acta Hort. 682:1535-1542, doi: 10.17660/ActaHortic.2005.682.204. 